\title{
A Climatic Model for Pecan Production under Humid Conditions
}

\author{
Darrell Sparks ${ }^{1}$ \\ Department of Horticulture, University of Georgia, Athens, GA 30602
}

Additional index words. alternate bearing, Carya illinoensis, Cladosporium caryigenum, climatic variation, drought, heating degree-days, rainfall, stress, temperature

\begin{abstract}
A multiple regression model was developed from historical data, 1945-92, to predict pecan [Carya illinoensis (Wangenh.) C. Koch] production in a humid climate. Variables were production trend (year of production), previous year's production, and climatic indices for the previous and current year. Production trend was used to measure change in production with time. Previous year's production was the index of alternate bearing. Variables for previous year's climate were heating degree-days for April-October and cumulative rainfall during May-July and 1-15 Sept. Variables for current year's climate were cumulative rainfall during April-August and 1-15 Sept. The indicator used for scab [Cladosporium caryigenum (Ell. \& Langl.) Gottwald] infection was the highest cumulative sum of 2 or more days of consecutive rain occurring in May, June, or 1-15 July. The $R^{2}$ for the model was 0.908. Production trend was the most important factor influencing production during the 1945-92 study period. Importance of the other variables in decreasing order were previous year's rainfall in May-July, consecutive rainy days, previous year's production, current year's 115 Sept. rainfall, previous year's heating degree-days, previous year's rainfall for 1-15 Sept., and current year's rainfall during April-August. Previous year's conditions had a greater effect on production than current year's. The recent decline in pecan production in the southeastern United States is due to an unfavorable change in climate.
\end{abstract}

Humid climates are dynamic. Extreme deviations in climate greatly influence crop productivity. One extreme climatic event can affect pecan production for 2 or more years (Hunter, 1963). Long-term effects occur because fruiting in pecan, as in other tree crops, is a function of conditions existing the year before and during fruiting (Davis and Sparks, 1974; Lockwood and Sparks, 1978). Pecan pistillate flowers are produced from substrates accumulated during the previous year's growing season (Lockwood and Sparks, 1978), with the number of pistillate flowers being fixed by the time of budbreak (Wetzstein and Sparks, 1986). Thus, maximum potential nut production (fruit numbers) for the season is determined at the time of budbreak and is a direct function of conditions in the previous growing season. The potential nut production realized is dictated by conditions affecting subsequent fruit development.

Irregular bearing, a major problem in pecan production (Sparks, 1983), was proposed by Hunter (1963) to be dominated by pronounced climatic deviations. Irregular bearing is minimal and production tends to increase with time when no extreme climatic deviations occur over consecutive years. However, various climatic extremes may induce irregular bearing. Prolonged cloudy conditions and excessive rainfall during a heavy crop year may induce irregular bearing the next year. Severe, season-long drought can likewise induce irregular bearing (Hunter, 1963). Even severe short-term droughts, common in late August and early September in the southeastern United States, can cause premature defoliation (Alben, 1958; Sparks, 1992c) that suppresses return bloom (Hinrichs, 1962; Moznette, 1934; Worley, 1979), especially on heavily fruiting trees (Sparks, 1983; Sparks and Brack, 1972).

The current year's climatic conditions largely control attainment of the pecan production potential by influencing the develop-

Received for publication 22 Feb. 1996. Accepted for publication 3 June 1996 Appreciation is expressed to Gloria Belvan for the tedious calculations. The cost of publishing this paper was defrayed in part by the payment of page charges. Under postal regulations, this paper therefore must be hereby marked advertisement solely to indicate this fact.

'Professor of horticulture. ment from flower to fruit (Alben, 1958; Sparks, 1989a, 1995a, 1995b; Stein et al., 1989). Nut quality is good with optimum rainfall throughout the growing season. Fruit elongation is maximized in May and June; fruit expansion from mid-July to midAugust (Sparks, 1995a); and kernel development in September (Andrews and Sherman, 1980; Sparks, 1992a). Inadequate rainfall during one or more of these stages will negatively impact fruit development. Dry conditions during May, June, or July produce small nuts (Sparks, 1989a) that become well filled if soil moisture is adequate during filling in September (Magness, 1955). The nut will be large but poorly filled under condition of adequate soil moisture during fruit elongation and expansion followed by inadequate moisture during kernel development (Andrews and Sherman, 1980; Magness, 1955; Sparks, 1992a). Kernel development and quality are suppressed by excessive rain during the growing season (Hunter, 1963; Schaller et al., 1968; Sparks et al., 1995). On the other hand, inadequate soil moisture causes fruit abortion (Gammon et al., 1955; Sparks, 1989a).

Potential production is also influenced by scab (Cladosporium caryigenum), the major foliage and fruit disease in pecan. The development of scab is triggered by rains (Latham, 1982; Sparks, 1995b), and the disease can greatly suppress fruit growth and production of susceptible cultivars. Foliage is susceptible during leaf expansion in April and May, but not after leaves are fully expanded (Demaree, 1924; Gottwald, 1985; Valli, 1964). The fruit are susceptible from May to September (Gottwald and Bertrand, 1982). Scab infection on the foliage reduces photosynthesis efficiency (Gottwald and Wood, 1984), but the main effect of severe infection is suppression of leaf size and/or defoliation (Diener and Garrett, 1967). Damage from scab is most severe when the fruit are small in May and June. Damage decreases as fruit development progresses (Gottwald and Bertrand, 1982).

The apparent dominant relationship of nut production to previous and current climatic conditions suggests that pecan production might be predicted with acceptable precision from climatic factors. The objective of this study was to develop a model for predicting pecan nut production under humid conditions based on variation of climatic conditions. A model would be valuable to predict nut 


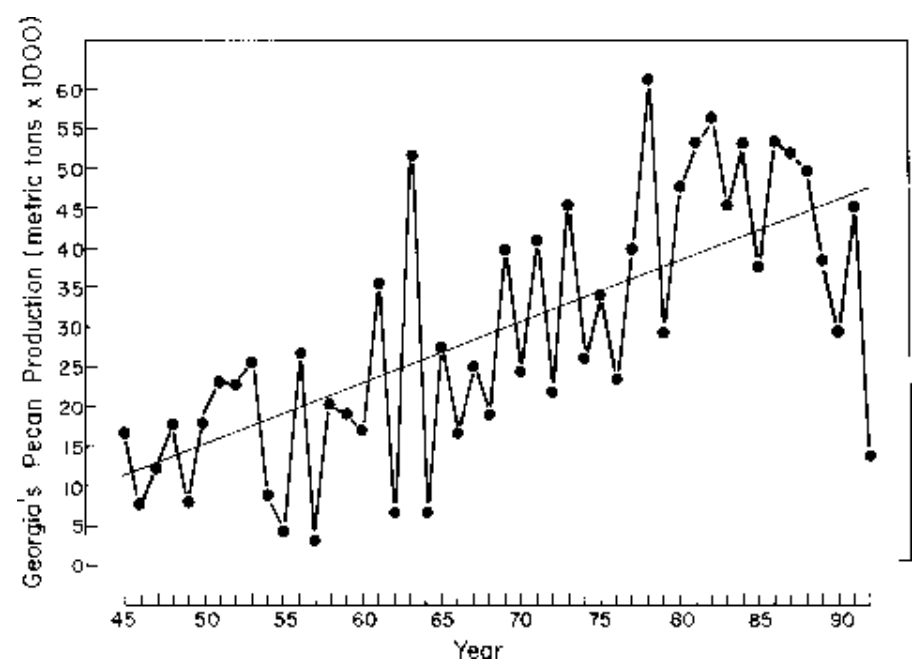

Fig. 1. Pecan nut production in Georgia, 1945-92. The relationship of production to time (diagonal line) is $\mathrm{Y}=-22.17+0.76 \mathrm{X}, r^{2}=0.4474, P \leq 0.05$.

production and to assess the relative importance of individual factors on production.

\section{Materials and Methods}

Georgia's nut production was selected for modeling because it accounts for about $50 \%$ of the total United States production (Wetzstein and Sparks, 1986) and the orchards consist almost entirely of pecan cultivars. Nuts from cultivars have a higher market value than nuts from native tree stands, therefore, orchards receive better management than native groves (Reid and Eikenbary, 1990; Sparks, 1980). Furthermore, estimates from states with a predominance of native stands (e.g., Arkansas, Louisiana, Mississippi, Oklahoma, and Texas) are not always reliable because the percentage of the crop harvested from one year to the next depends on prevailing market price of the nut. Crops may not be harvested in years of low market prices.

Production records (Fig. 1) used for modeling were reported by the Georgia Agricultural Statistics Service (Snipes, 1995) for the 48-year period 1945-92. Georgia records for 1943, 1944, and 1993 were used for model validation. Data before 1943 were excluded because of widespread zinc deficiency (Sparks, 1987). The year 1955 was not modeled, as most of the crop was destroyed by a late spring freeze (Hunter, 1963). The relationship of the Georgia estimates was compared with nut production from a single 383-ha orchard for $1950-92$. The correlation $\left(r^{2}=0.725\right)$ supports validity of estimates from the reporting service.

Eight variables were used for modeling nut production (Table
1). Production year was used to measure change, i.e., trend, in production with time. The relationship of nut production with time was positive and linear (Fig. 1). Increased production with time is assumed to reflect increases in tree size and acres planted, improvements in tree nutrition; advances in pecan weevil [Curculio caryae (Horn)], hickory shuckworm [Laspeyresia caryana (Fitch)], black pecan aphid [Melanocallis caryae foliae (Davis)], and scab control; and some installation of solid-set sprinkler and dripirrigation systems beginning in the late 1970s. Pecan production in a given year is influenced by the production level during the previous year (Sparks, 1983; Fig. 1). In the model, previous year's production was used as the index of this alternate bearing influence.

Intermittent, variable cloud cover is a normal climatic condition in a humid climate that influences sunlight and temperature in the tree canopy. Heating degree-days were used to estimate the effect of sunlight and temperature and are assumed to be an overall indication of ambient photosynthetic conditions. One heating degree-day was accumulated for each degree that the daily mean ambient temperature was above base $18.3^{\circ} \mathrm{C}$. The mean temperature is the average of the maximum and minimum for the day. A $18.3^{\circ} \mathrm{C}$ base was chosen as suitable for pecan growth and development (Sparks, 1989b). Previous year's heating degree-days were accumulated daily from 1 Apr. to 31 Oct., and current year's heating degree-days were accumulated daily from 1 June to 30 Sept. The interval from 1 Apr. to 31 Oct. is the period of photosynthetic activity for the pecan tree (Mielke, 1981), and from 1 June to 30 Sept. encompasses most of the fruit growth (Davis and Sparks, 1974).

The indicator used for scab severity during the current year was the highest cumulative sum of 2 or more days of consecutive rain occurring in either May, June, or in the first 15 days of July. For example, in a given year, if the sum was 10,2, and 9 days for May, June, and 1-15 July, respectively, 10 days were used. Two or more days of consecutive rain is critical because scab infection follows rain (Latham, 1982; Sparks, 1995b), with maximum infection following 2 days of continuous leaf wetness over a wide temperature range (Gottwald, 1985; Valli, 1964). May, June, and early July were selected because leaf infection is usually highest in May (Latham, 1982), and scab infections on the fruit in May, June, and early July can result in total fruit loss or unmarketable kernels (Gottwald and Bertrand, 1982). The assumption was made that scab damage is proportional to the most intense rain period. Thus, highest cumulative sum by month and not the total for the 3 months was used.

Current rainfall for April-August and for 1-15 Sept. were included as variables. April-August encompasses leaf expansion (Davis and Sparks, 1974) and fruit enlargement (Sparks, 1986), which is governed by soil moisture (Finch and Van Horn, 1936;

Table 1. Variables used for modeling pecan nut production.

\begin{tabular}{|c|c|c|}
\hline Variable & Mean & $\mathrm{SD}( \pm)$ \\
\hline $\mathrm{Y}=$ Georgia's nut production (metric tons) & 29,906 & 15,685 \\
\hline$X_{1}=$ Production trend $1945-92$ or $45-92$ (year) & 68.8 & 13.9 \\
\hline $\mathrm{X}_{2}=$ Previous year's nut production (metric tons) & 29,843 & 15,793 \\
\hline $\mathrm{X}_{3}=$ Previous year's heating, April-October (degree-days) & 1,275 & 96.4 \\
\hline $\mathrm{X}_{4}=$ Current year, 2 or more consecutive rainy days, highest sum in May, June, or 1-15 July (days) & 8.9 & 2.6 \\
\hline $\mathrm{X}_{5}^{4}=$ Current year's cumulative rain, $1-15$ Sept. $(\mathrm{mm})$ & 43 & 13 \\
\hline $\mathrm{X}_{6}=$ Current year's cumulative rain, April-August $(\mathrm{mm})$ & 554 & 115 \\
\hline $\mathrm{X}_{7}=$ Previous year's cumulative rain, May-July (mm) & 351 & 89 \\
\hline $\mathrm{X}_{8}=$ Previous year's cumulative rain, $1-15$ Sept. (mm) & 43 & 13 \\
\hline
\end{tabular}


Fig. 2. Relationship , of predicted vs. Georgia's nut production, 1945-92. The relationship ; is described by $\mathrm{Y}=2.7397+$ $0.9084 \mathrm{X}, \quad r^{2}=$ : 0.9084, SEE $=$ $\pm 4624, P \leq 0.05$.

Sparks, 1989a, 1995a). Current season's rainfall in September influences produc-


tion, as this month is the major period of kernel development (Davis and Sparks, 1974). Nut weight is about 50\% kernel and kernel growth is water dependent (Alben, 1958; Andrew and Sherman, 1980; Stein et al., 1989). The 1-15 Sept. interval was used because of being critical to kernel development (Sparks, 1992a).

The intervals for previous year's rainfall were May-July and 115 Sept. Deficient (Stein et al., 1989) or excessive soil moisture (Hunter, 1963) in the previous year reduces production the following year. Observations indicate that a critical rainfall interval is May-July. The rationale for using 1-15 Sept. as a critical rainfall interval was that water stress during this time, simultaneously coupled with the stress of kernel development, would be expressed as reduced return bloom during the following year.

Heating degree-days and rainfall data were averages of conditions in Albany and Cordele, Ga. These two locations are in the major pecan production area of Georgia and their climates appear to be indicative of the pecan growing region (Sparks, 1989b).

The relationship of nut production to the variables was delineated by multiple regression analyses (Ezekiel and Fox, 1959). The equation producing the lowest standard error of the estimate (SEE) and with all partial regression coefficients statistically different $(P$ $\leq 0.05$ ) from 0 was used as the final model. During the development of the model, minimization of the SEE was also used to confirm the optimum intervals for heating degree-days, rainfall, and number of consecutive rainy days. For example, the previous



Fig. 3. D̂istribution of yield residuals with time resulting from the model used to predict Georgia pecan production.

year's rain for 1-15 Sept. produced the lowest SEE compared with rain in either August, September, mid-August to mid-September, or August plus September, etc.

The graphical relationship of nut production to individual variables was calculated by holding the trend factor constant at 84 for 1984 and using the average values for all variables except the one being analyzed. Relative importance of the individual variables on nut production was evaluated by partial $r^{2}$. The graphical relationships illustrate the degree nut production can be affected by the variables in a given year, whereas, the partial $r^{2}$ s indicates the importance over years.

Nut production during the study period was standardized to examine variations in climate on relative production. Production was standardized by calculating the effect of previous and current climatic conditions on production with a fixed base for trend and previous year's nut production (alternate-bearing index). Bases were the trend for 84 or the year 1984 and the previous year's production of 45,359 metric tons.

\section{Results and Discussion}

The best equation for modeling nut production was $\mathrm{Y}=14.6634+$ $1.4273 \mathrm{X}_{1}-0.4561 \mathrm{X}_{2}+0.0611 \mathrm{X}_{3}-1.9852 \mathrm{X}_{4}-5.3302\left(1 / \mathrm{X}_{5}\right)-0.2010 \mathrm{X}_{6}$ $+9.9630 \sqrt{X_{6}}-7.9445 \sqrt{ } X_{7}-1855.36\left(1 / \sqrt{ } X_{7}\right)-7.8672\left(1 / X_{8}\right)$, where $X_{1}$

Table 2. Accuracy of pecan nut production predicted from the climatic model.

\begin{tabular}{|c|c|c|c|c|}
\hline \multirow[b]{2}{*}{ Year } & \multirow[b]{2}{*}{ Event/note } & \multicolumn{3}{|c|}{ Metric tons $\times 1000$} \\
\hline & & $\begin{array}{l}\text { Observed } \\
\text { production }\end{array}$ & $\begin{array}{l}\text { Predicted } \\
\text { production }\end{array}$ & $\begin{array}{l}\text { Observed - } \\
\text { predicted }\end{array}$ \\
\hline$\overline{1954}$ & Record dry 1-15 Sept. & 9.1 & 5.9 & 3.2 \\
\hline 1956 & Recovery from 1955 freeze & 27.2 & 34.7 & -7.5 \\
\hline 1957 & Recovery from 1955 freeze & 3.4 & 11.9 & -8.5 \\
\hline 1958 & Recovery from freeze completed & 20.4 & 23.7 & -3.3 \\
\hline 1963 & Record production & 51.7 & 45.7 & 6.0 \\
\hline 1964 & Record rain, April-August & 6.8 & 6.9 & -0.1 \\
\hline 1978 & Record production & 61.2 & 56.3 & 4.9 \\
\hline 1986 & Record drought, April-August & 54.4 & 49.9 & 4.5 \\
\hline 1991 & Record dry, 1-15 Sept.: near record rain, April-August & 45.4 & 48.0 & -2.6 \\
\hline 1992 & 28-year production low & 13.6 & 13.4 & 0.2 \\
\hline 1994 & Massive, extended flood in southwestern Georgia & 29.5 & 48.9 & -19.4 \\
\hline 1943 & Model validation & 13.8 & 6.5 & 7.2 \\
\hline 1944 & Model validation & 15.2 & 18.8 & -3.6 \\
\hline 1993 & Model validation and record production & 68.0 & 67.1 & 0.9 \\
\hline
\end{tabular}


Fig. 4. Relationship of current year pecan production to the previous year's production.

$=$ production trend or year, 45-92 (year), $\mathrm{X}_{2}=$ previous year's nut production (metric tons), $\mathrm{X}_{3}=$ previous year's heating, AprilOctober (de-

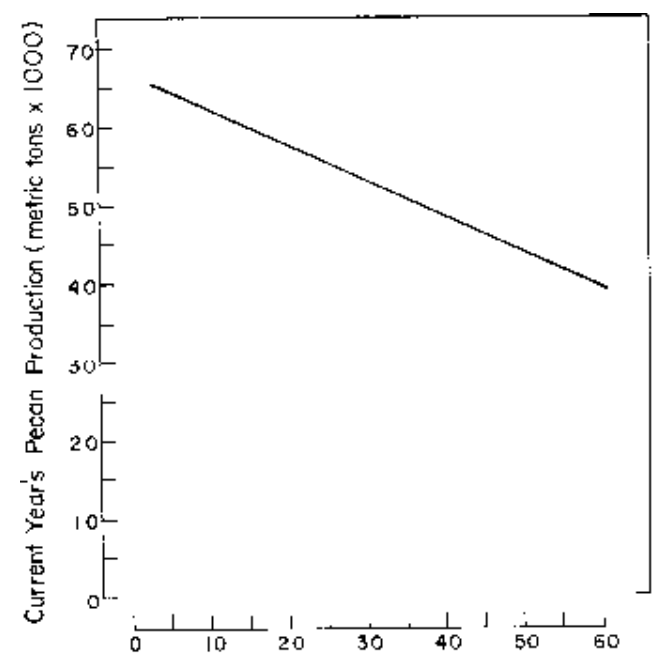

Prewious Year's Pecon Production ‘ metric tons $\times 1000$ ! gree days), $\mathrm{X}_{4}=$ current year's rain, 2 or more consecutive rainy days, highest cumulative sum occurring in May, June, or 1-15 July (days), $\mathrm{X}_{5}=$ current year's cumulative rain, 1-15 Sept. (mm), $\mathrm{X}_{6}$ = current year's cumulative rain, April-August $(\mathrm{mm}), \mathrm{X}_{7}=$ previous year's cumulative rain, May-July $(\mathrm{mm})$, and $\mathrm{X}_{8}=$ previous year's cumulative rain, 1-15 Sept. (mm)

All partial regression coefficients are significantly different from $0, \leq 0.05$. The $R^{2}$ is 0.908 and the SEE is \pm 5424 metric tons. The nut production predicted from the model compared to recorded Georgia pecan production is acceptable (Fig. 2). Yield residuals were randomly distributed over years (Fig. 3) indicating the model was not appreciably biased with time.

The model adequately predicted production associated with extreme climatic events (record dry and wet periods) and in years of extreme production $(1963,1978$, and 1993) including the 28year low of 1992 (Table 2). All were predicted with less error than the SEE of the model, \pm 5424 metric tons, except the record production for 1963. Production for the years used for model validation1943, 1944 and 1993 — was also predicted with acceptable accuracy. The model failed to predict production for 1994, the year of massive and extended flooding in southwest Georgia. Also, the model over predicted production during the 1956-57 recovery from the major freeze in 1955 (Hunter, 1963), although predictions were well within the error of the model. Nevertheless, the model should be used cautiously during recovery from a major freeze. Over prediction following flooding and freezing occurred because the model does not include a variable to measure flood

Fig. 6. Pecan production as a function of the highest sum of days with 2 or more consecutive rainy days in May, June, or 1-15 July.

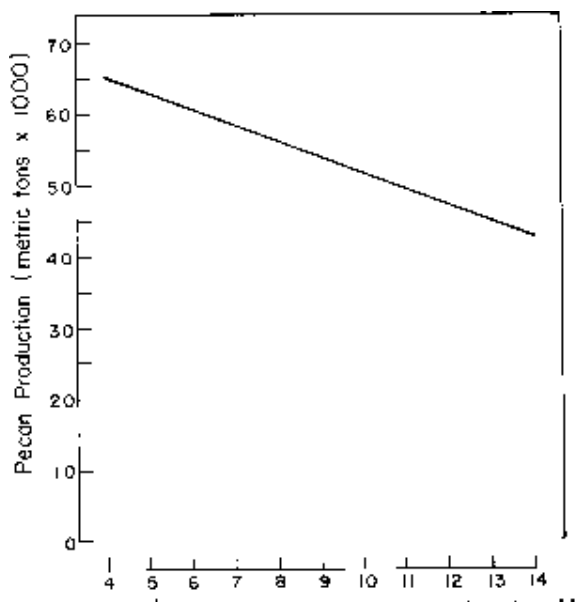

Current Year's Fiain, two or more consecutive doys, May, لduse, or $!-15$ ل $151 y$
Previdus Yeor's Heating Degree Days, April-Oetcber



Fig. 5. Relationship of pecan production to previous year's heating degree-days.

nor freeze damage. However, this is not considered a major flaw in the model, as the 1994

flood was an event last happening 100 years ago and the 1955 freeze 60 years ago.

Extreme discrepancies between observed

and predicted production of 8300 to 10,800 metric tons occurred for 1965, 1972, 1982, 1983, and 1990. Predicted production was less than observed for 1965, 1972, 1982, and 1983 and more than observed for 1990. In all these years except 1990, days of consecutive rain (the indicator for scab severity) were high at about 11 . Data confirmed that scab was a major problem in these years (Bertrand and Gottwald, 1984; Diener and Garrett, 1967; Latham and Garrett, 1973). The possibility exists that the Georgia Agricultural Statistics Service failed to give sufficient weight to scab damage in these years. A reason for the discrepancy for 1990 is not apparent.

Relationship of nut production to production trend, previous year's production, previous year's heating degree days, and days of consecutive rain in May, June, or 1-15 July is linear as determined by the modeling equation and illustrated by Figs. 1 and 4-6. Relationship of nut production to previous and current season rainfall is curvilinear (Figs. 7 and 8). Extremes in previous year's production (Fig. 4), previous year's heating degree-days (Fig. 5), consecutive rainy days (Fig. 6), and rainfall during the previous and current year (Figs. 7 and 8) can have a pronounced influence on nut production in a given year.

The relative importance of the individual variables varied greatly (Table 3). By far, production trend had a greater effect on pecan production than any other factor. Production over the study period increased 4-fold at about 0.76 metric tons per year (Fig. 1). Previous year's nut production, the alternate-bearing index, was

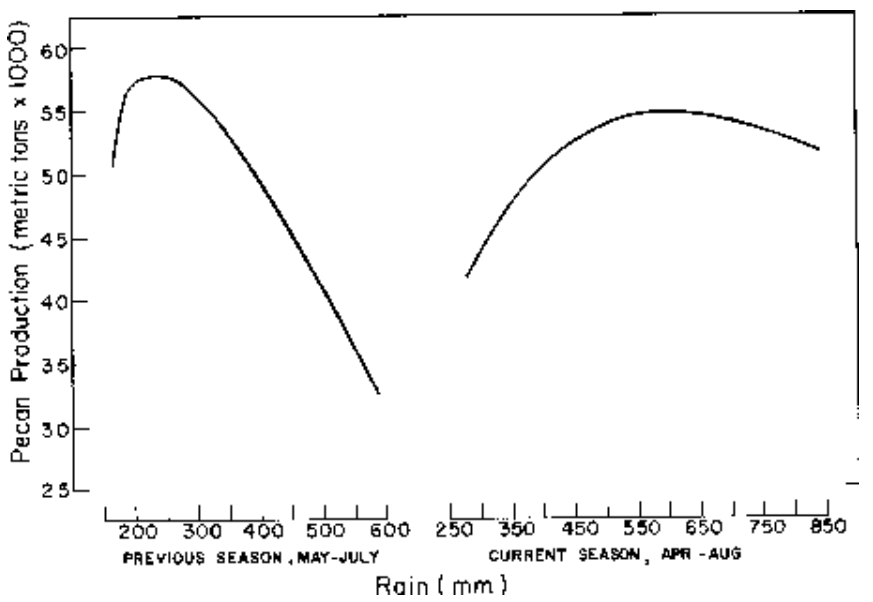

Fig. 7. Graphical relationship of pecan nut production to previous year's rainfall in May-July and current year's rainfall in April-August. Rainfall is cumulative in each interval. 
Fig. 8. Graphical relationship of pecan nut production to current year's and previous year's cumulative rainfall from $1-15$ Sept.

the fourth most important factor. The less than predominant role of alternate bearing is contrary to general opinion, but is not surprising in that production can increase or de-


crease for 2 or more years without alternate bearing (Fig. 1). In fact, classical alternate bearing occurred only for one prolonged period, 1960-76. Following this period, production increased for 2 years with record production occurring in 1978. Based strictly on alternate bearing, 1978 should have been an "off" year. Variation in production is not necessarily alternate as production is influenced by factors in addition to previous year's fruiting intensity. Therefore, irregular bearing is more descriptive of cyclic pecan production than alternate bearing.

Previous year's rain for May-July was the most important climatic factor influencing pecan production (Table 3 ) and had an effect about 10 times greater than current year's rain in AprilAugust. Soil moisture in the previous year affects the number of nuts produced (Stein et al., 1989), whereas current year's moisture affects nut size (Finch and Van Horn, 1936). Current year's soil moisture has less effect on nut production because pecan production is dominated by nuts per tree and not by nut size (Sparks, $1992 b)$. The curvilinear relationship of nut production to rain in the previous and current year (Fig. 7) shows that pecan nut production is sensitive to deficit and excessive soil moisture, as proposed by Hunter (1963). Excessive soil moisture induces prolonged reduction in photosynthesis (Smith and Ager, 1988) and suppresses leaf growth (Smith and Bourne, 1989), consequently suppressing flower formation by limited substrates (Lockwood and Sparks, 1978). Waterlogging has less effect on current year production than the dramatic suppression of following year production. The primary effect of waterlogging during the current year is due to inducing shuck decline (Sparks et al., 1995) and associated poor kernel development. Shuck decline usually occurs late in fruit develop- ment (Schaller et al., 1968), and production is reduced mainly because of suppressed kernel development. At the time shuck decline occurs, shell (which is about $50 \%$ of the nut weight) development is near completion. For this reason, suppressed kernel growth late in development does not result in a striking reduced production (Fig. 7). However, the effect on edible or marketable kernels can be pronounced (Sparks et al., 1995).

Consecutive rainy days in May, June, or 1-15 July, the index of scab infection, was the second most important climatic factor (Table 2). This is not surprising, as the recommended control program (Ellis et al., 1991) does not adequately control scab in seasons of high scab pressure (Latham and Campbell, 1991; Sparks, 1995b).

Rain during the first 15 days of September of the current year was the third most dominant climatic factor (Table 3). Current season's rain had about twice the effect on nut production as the previous year's rainfall for 1-15 Sept. Rainfall the first 2 weeks of September can have a dramatic effect of production (Fig. 8). The 2-week period is critical because it coincides with the beginning of rapid kernel development (Davis and Sparks, 1974) and because kernel development at this time is crucial dependent on soil water (Sparks, 1992a). The effect of soil moisture on kernel development is expected as September is historically the second driest month of the year and about one half of the total nut weight accumulates during this month. Effects of drought during 1-15 Sept. of the previous year are presumed due to suppressed substrate accumulation from reduced leaf efficiency (Loustalot, 1945; Mielke, 1981; Rieger and Daniell, 1988) or, in extreme cases, to droughtinduced defoliation. Extreme drought during the previous year affects production more than does similar drought in the current year (Fig. 8).

Previous year's degree-day accumulation was the fourth most important climatic factor (Table 3). Years with high production during the 1945-92 study period were associated with aboveaverage heating degree-days. The relationship of production to heating degree-days supports the contention that low sunlight reduces next year's nut production(Hunter, 1963). Current season's heating degree-days were originally included in the model, but were not statistically significant. Because pistillate flower production is fixed at budbreak (Wetzstein and Sparks, 1986), any effect of current season heating would be on nut size and kernel development. As indicated earlier, nut size is a relatively minor component of total production (Sparks, 1992b). Nut size and kernel development are dominated by soil moisture (Finch and Van Horn, 1936; Sparks, 1989a), not heat variations.

The summation of the partial $r^{2}$ (Table 3) for previous year's factors is 0.2821 . The sum for the current year's factors is 0.179 . Previous year's factors have about 1.6 times more influence on current season production than current season's factors. If the

Table 3. Importance of dependent variables on pecan production.

\begin{tabular}{lc}
\hline \hline $\begin{array}{l}\text { Dependent } \\
\text { variable }\end{array}$ & Partial \\
Production trend $^{2}$ & 0.4474 \\
Previous year's nut production & 0.0549 \\
Previous year's heating degree-days & 0.0326 \\
Current year, days of consecutive rain in May, June, or 1-15 July & 0.1100 \\
Current year's rain, 1-15 Sept. & 0.0526 \\
Current year's rain, April-August & 0.0164 \\
Previous year's rain, May-July & 0.1679 \\
Previous year's rain, 1-15 Sept. & 0.0267 \\
Total & 0.9085 \\
\hline
\end{tabular}




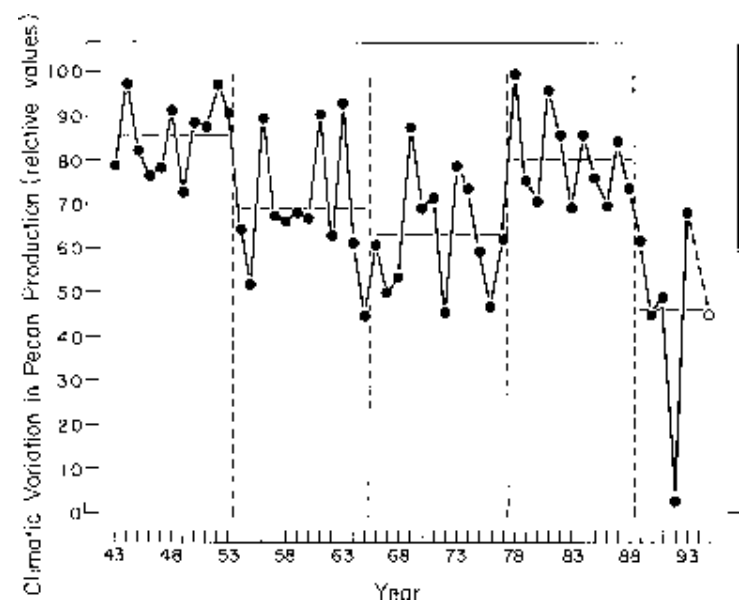

Fig. 9. Climatic variation in pecan production from 1943-95. The relationship shows the effect of climate as such on nut production. The nonclimatic factors, production trend and year's production, are held constant. The vertical lines delineate production periods. The horizontal line within each period is the mean for the period. The line drawn from the open circle, 1995, to the solid circle 1993 is assumed, as the model does not adequately predict 1994.

sums include only climatic factors, the partial $r^{2}$ for previous season's factors is 0.2272 and the current year's factors is 0.179 , showing that previous year's climate has more effect on production than does current year's climate.

Although production trend was the dominant factor affecting production over time, it is relatively minor in a given year. The effect of trend is a constant within a year, whereas the effect of the other factors affecting production has the potential to vary greatly (Figs. 4-8). Thus, production for a given year is mainly a function of previous year's production and the climate of the previous and current year. The sum of the partial $r^{2}$ (Table 3 ) for climatic factors $(0.4062)$ is about 7.5 times greater than the partial $r^{2}$ for previous year's production (0.0549), indicating the predominant dependence of pecan production in a humid environment on variation of climatic factors. The climatic factors are mainly rainfall related. Sum of partial $r^{2}$ for rainfall factors, including the scab index, is about 11.5 times greater than the partial $r^{2}$ for heating degree-days.

The dominating influence of climate is also evident when the effects of production trend and previous and current year's production are held constant (Fig. 9). Variation in relative production is proposed to occur in periods of 11 to 12 years. Division of periods was based on variation among years and on magnitude of relative production. The first period was very favorable for nut production, the second and third periods were less favorable, and the fourth period was favorable. Beginning in 1989, a major reversal occurred and relative pecan production reached an all time low in 1992, after which production improved but remained below normal. Real production (Fig. 1) followed a similar trend, and, in 1992, nut production reached a 28-year low. Pecan production in the southeastern United States has followed a similar trend (Pena, 1995). The correlation of real production with relative production during 1989-95 indicates that decline in regional production was due to an unfavorable climate.

Usually, years of high or record pecan production, e.g., 1963 and 1978, have been associated with optimum or near optimum climates (Fig. 1 vs. 9). However, record production can occur under less than optimum weather conditions if the previous year's production is abnormally low. This was the situation during 1993 when production was at an all time high.

Once the current growing season is completed, the model can be used to predict production for the following year under assumed conditions. Such a prediction would be valuable in making marketing decisions. For example, if the prospects are poor for a good return bloom, nuts from the current year can be placed in storage for next year's market. If prospects are high for a good return bloom, storing nuts would likely be an unprofitable decision. For instance, the prospects for an excellent return bloom in 1996 are very good because of the favorable climate existing in 1995. If the climatic factors for 1996 are average (1945 to 1992), production in 1996 is predicted to be 77,233 metric tons, which would be a record production. Thus, storing part of the 1995 crop would be a risky decision.

The model can be used to predict production assuming adverse climatic conditions. If September is dry in 1996, predicted production is reduced from 76,765 to 55,905 metric tons. If the dry September is preceded by high scab pressure as occurred in 1991, predicted production is further reduced to $46,698 \mathrm{t}$.

Climatic factors influencing nut production manageable by the grower are scab from frequent rains, drought, and, indirectly, sunlight. The current scab control program (Ellis et al., 1991) gives poor control during seasons of high scab pressure (Latham and Campbell, 1991; Sparks, 1995b). A new approach to scab control has been proposed (Sparks, 1995b) and is currently being evaluated. Whatever the preventive program used, scab control can be greatly improved by minimizing mutual shading among trees.

Disastrous droughts occur mainly in late August through September. The $148 \mathrm{~mm}$ of rain per hectare needed during 1-15 Sept. for maximum kernel development (Sparks, 1992a) is often deficit. During the 1945-92 study period, <148 $\mathrm{mm}$ of precipitation occurred during the critical period in about $60 \%$ of the years. Since the importance of water in September was reported (Sparks, 1992a), many growers have been irrigating during early September with improved kernel quality and return bloom. The detrimental effect of excessive moisture from prolonged rains can be minimized by selecting pecan sites with adequate surface drainage. In this regard, return bloom following the excessive rains in 1994 was much better in orchards situated on slopes or ridges than in orchards on flat sites (Sparks, 1995c). Many pecan orchards are overcrowded, with a major reduction in photosynthesis from mutual shading (Andersen and Brodbeck, 1995; Mielke, 1981) and greatly reduced tree productivity (Hinrichs, 1961). The use of available sunlight and tree productivity can be improved by thinning crowded trees (Alben, 1958; Alben and Sitton, 1950; Crane et al., 1934; Romberg et al., 1959).

The climatic model predicts pecan nut production with acceptable precision. The major limitation of the model is that production is assumed to be linear with time. If production deviates from linearity, the model must be adjusted accordingly. Furthermore, but of lesser importance, the model will not adequately predict production following either a major freeze or a major flood. The model clearly defines factors influencing pecan production in a humid climate and indicates areas for improved management. Additionally, the model can be used as a tool for planning marketing strategies.

\section{Literature Cited}

Alben, A.O. 1958. Results of an irrigation experiment on Stuart pecan trees in east Texas in 1956. Proc. Southeastern Pecan Growers Assn. 51:61-68.

Alben, A.O. and B.G. Sitton. 1950. Fourteen years' results of thinning the stand of trees in a pecan orchard on alluvial soil. Proc. Amer. Soc. Hort. Sci. 56:98-102.

Andersen, P.C. and B.V. Brodbeck. 1995. Light preconditioning and fluctuating irradiance levels influence gas exchange of pecan leaves, $p$. 
148-159. In: M.W. Smith, W. Reid, and B.W. Wood. (eds.). Sustaining pecan productivity into the 21st century. USDA-ARS 1955-3.

Andrews, C.P. and W.B. Sherman. 1980. Reduction in percent kernel as influenced by prolonged autumn drought. Proc. Southeastern Pecan Growers Assn. 73:159-161.

Bertrand, P.F. and T.R. Gottwald. 1984. The effect of deletion of late season fungicide sprays on pecan yield and quality. Proc. Southeastern Pecan Growers Assn. 77:51-54.

Crane, H.L., M.B. Hardy, N.H. Loomis, and F.N. Dodge. 1934. Growth and yield of pecan trees, as affected by thinning the stand of trees and other orchard practices. Proc. Amer. Soc. Hort. Sci. 32:33-37.

Davis, J.T. and D. Sparks. 1974. Assimilation and translocation patterns of carbon-14 in the shoot of fruiting pecan trees, Carya illinoensis Koch. J. Amer. Soc. Hort. Sci. 99:468-480.

Demaree, J. B. 1924. Pecan scab with special reference to sources of early spring infections. J. Agr. Res. 38:321-330.

Diener, U.L. and F.E. Garrett. 1967. Summary of three years results for pecan disease control in Alabama. Proc. Southeast Pecan Growers Assn. 60:36-43.

Ellis, H.C., J. Hadden, T.C. Crocker, and S. Brown. 1991. Georgia pecan spray guide. Univ. Georgia Coop. Ext. Ser. Bul. 841.

Ezekiel, M. and K.A. Fox. 1959. Methods of correlation and regression analysis. Wiley, New York.

Finch, A.H. and C.W. Van Horn. 1936. The physiology and control of pecan nut filling and maturity. Arizona Agr. Sta. Tech. Bul. 62.

Gammon, N., R.H. Sharpe, and R.G. Leighty. 1955. Relationship between depth to heavy-textured subsoil and drought injury to pecans. Soil Sci. Soc. Florida Proc. 15:31-34.

Gottwald, T.R. 1985. Influence of temperature, leaf wetness period, leaf age, and spore concentration on infection of pecan leaves by conidia of Cladosporium caryigenum. Phytopathology 75:190-194.

Gottwald, T.R. and P.F. Bertrand. 1982. Effect of time of inoculation with Cladosporium caryigenum on pecan scab development and nut quality. Phytopathology 73:714-718.

Gottwald, T.R. and B.W. Wood. 1984. The effects of scab and powdery mildew on photosynthesis and respiration of pecan fruit and foliage. Proc. Southeastern Pecan Growers Assn. 77:139-143.

Hinrichs, H.A. 1961. The relationship of native pecan tree spacing to yield. Oklahoma State Univ. Agr. Expt. Sta. Bul. B-574.

Hinrichs, H.A. 1962. Pecan industry and some research developments in Oklahoma. Annu. Rpt. Northern Nut Growers Assn. 53:80-85.

Hunter, J.H. 1963. Pecan-production cycles as related to weather in Georgia. Proc. Southeastern Pecan Growers Assn. 56:10-12.

Latham, A.J. 1982. Effects of some weather factors and Fusicladium effusum conidium dispersal on pecan scab occurrence. Phytopathology 72:1339-1345.

Latham, A.J. and H.L. Campbell. 1991. Evaluation of selected fungicides for control of scab and anthracnose of pecans. Proc. Southeastern Pecan Growers Assn. 84:78-83.

Latham, A.J. and F.E. Garrett. 1973. Control of pecan scab in Alabama during 1972. Proc. Southeastern Pecan Growers Assn. 66:149-152.

Lockwood, D.W. and D. Sparks. 1978. Translocation of ${ }^{14} \mathrm{C}$ in 'Stuart' pecan in the spring following assimilation of ${ }^{14} \mathrm{CO}_{2}$ during the previous growing season. J. Amer. Soc. Hort. Sci. 103:38-45.

Loustalot, A.J. 1945. Influence of soil moisture conditions on apparent photosynthesis and transpiration of pecan leaves. J. Agr. Res. 71:519-532.

Magness, J.H. 1955. Practicability of irrigating pecan orchards in the southeastern states. Proc. Southeastern Pecan Growers Assn. 48:23-29.

Mielke, E.A. 1981. Effect of stress on pecan photosynthesis. Western Pecan Conf. Proc. 15:47-69.

Moznette, G.F. 1934. Experiments in control of pecan black aphids under orchard conditions. Proc. Southeastern Pecan Growers Assn. 28:55-61.
Pena, J.G. 1995. Pecan/tree nut marketing season: an overview of production, prices and market collapse, p. 88-109. In: M.W. Smith, W. Reid, and B.W. Wood. (eds.). Sustaining pecan productivity into the 21 st century. USDA-ARS 1955-3.

Reid, W. and R.D. Eikenbary. 1990. Developing low-input management strategies for native pecan orchards, p. 69-76. In: B. W. Wood and J. A. Payne (eds.). Pecan husbandry: challenges and opportunities. USDAARS-96.

Rieger, M. and J.W. Daniell. 1988. Leaf water relations, soil-to-leaf resistance, and drought stress in pecan seedlings. J. Amer. Soc. Hort. Sci. 113:789-793.

Romberg, L.D., C.L. Smith, and H.L. Crane. 1959. Effect of irrigation and tree re-spacing (thinning) on pecan tree growth and nut production. Proc. Texas Pecan Growers Assn. 38:60-75.

Schaller, C.C., F.N. Dodge, and G.E. KenKnight. 1968. Increased occurrence of shuck disease of pecan (Carya pecan). Plant Dis. Rpt. 52:189_ 190.

Smith, M.W. and P.L. Ager. 1988. Effects of soil flooding on leaf gas exchange of seedling pecan trees. HortScience 23:370-372.

Smith, M.W. and R.D. Bourne. 1989. Seasonal effects of flooding on greenhouse-grown seedling pecan trees. HortScience 24:81-83.

Snipes, L.E. 1995. Georgia agricultural facts. Georgia Agr. Stat. Serv., Athens.

Sparks, D. 1980. Energy requirement for pecan, Carya illinoensis (Wang.) K. Koch, p. 327-333. In: D. Pimentel (ed.). CRC handbook of energy utilization in agriculture. CRC Press, Inc., Boca Raton, Fla.

Sparks, D. 1983. Alternate fruit bearing in nut trees. Annu. Rpt. Northern Nut Growers Assn. 74:197-230.

Sparks, D. 1986. Pecan, p. 323-339. In: S.P. Monselise (ed.). CRC handbook of fruit set and development. CRC Press Inc., Boca Raton. Fla.

Sparks, D. 1987. Apparent effect of zinc treatment on the growth rate of pecan production and yield. HortScience 22:899-901.

Sparks, D. 1989a. Drought induces fruit abortion in pecan. HortScience 24:78-79.

Sparks, D. 1989b. Predicting nut maturity of the pecan from heat units. HortScience 24:454-455.

Sparks, D. 1992a. Pecan cultivars-The orchard's foundation. Pecan Production Innovations, Watkinsville, Ga.

Sparks, D. 1992b. In pursuit of a better pecan cultivar. Fruit Var. J. 46:174-182.

Sparks, D. 1992c. Stress factors affecting the Georgia pecan crop in 1991 and fruit set in 1992. Annu. Rpt. Northern Nut Growers Assn. 83:75-62.

Sparks, D. 1995a. Nut sizing period in pecan and soil water. Annu. Rpt. Northern Nut Growers Assn. (In press.)

Sparks, D. 1995b. A climatic approach to pecan scab control. HortTechnology 5:225-230.

Sparks, D. 1995c. Pecan fruit set following the wet 1994 growing season. The Pecan Grower 5(1):38.

Sparks, D. and C.E. Brack. 1972. Return bloom and fruit set of pecan from leaf and fruit removal. HortScience 7:131-132.

Sparks, D., W. Reid, I.E. Yates, M.W. Smith, and T.G. Stevenson. 1995. Fruiting stress induces shuck decline and premature germination in pecan. J. Amer. Soc. Hort. Sci. 120:43-53.

Stein, L.A., G.R. McEachern, and J.B. Storey. 1989. Summer and fall moisture stress and irrigation scheduling influence pecan growth and production. HortScience 24:607-611.

Valli, V.J. 1964. Weather conditions as related to pecan scab infection. Proc. Southeastern Pecan Growers Assn. 57:85-87.

Wetzstein, H.Y. and D. Sparks. 1986. Flowering in pecan, p. 217-255. In: J. Janick (ed.). Horticultural Reviews. AVI, Westport, Conn.

Worley, R.E. 1979. Fall defoliation date and seasonal carbohydrate concentration of pecan wood tissue. J. Amer. Soc. Hort. Sci. 104:195-199. 